Portland State University

PDXScholar

\title{
The Woman in White: Problems with Editorial History \& Classification of Genre in Proposing a New Edition
}

Andréa Franke

Portland State University

Follow this and additional works at: https://pdxscholar.library.pdx.edu/honorstheses

Let us know how access to this document benefits you.

\section{Recommended Citation}

Franke, Andréa, "The Woman in White: Problems with Editorial History \& Classification of Genre in Proposing a New Edition" (2014). University Honors Theses. Paper 98.

https://doi.org/10.15760/honors.58

This Thesis is brought to you for free and open access. It has been accepted for inclusion in University Honors Theses by an authorized administrator of PDXScholar. Please contact us if we can make this document more accessible: pdxscholar@pdx.edu. 
Franke 1

The Woman in White: Problems with Editorial History \& Classification of Genre in Proposing a New Edition

by

Andréa Franke

An undergraduate honors thesis submitted in partial fulfillment of the requirements for the degree of

Bachelor of Arts

in

University Honors

and

English

Thesis Adviser

Lorraine Mercer

Portland State University 
Franke 2

Special thanks to Professor Mercer of the English Department at Portland State for advising me through this process and reading all of my drafts from the beginning. Thank you to Professor Henningsgaard without whom I would have never realized the complexity of Editorial Theory, and to Professor Ensor who introduced me to Queer Theory. Also thank you to Professor Fallon and Professor Wheeler for listening to me in times of doubt and panic. 


\section{Preamble}

All members of the Honors College at Portland State University are required to write a senior thesis based on a topic within the student's major not only for the purposes of concluding a Bachelor's Degree, but also as a basis for graduate work if the student decides to seek further education. While students within the Honors College come from many different majors from both the sciences and the humanities, each student must go through the process of deciding the primary and secondary sources they wish to use in their research. It is likely my fellow humanities thesis writers, and those before me, went through a brief selection process in acquiring a certain edition of their primary source or sources. If the edition of the work was considered at all, it is likely the selection was based primarily on personal preference and whether or not it was a scholarly edition. After taking four credits for my senior thesis in the Summer of 2013, I enrolled in a course that caused me to rethink my uninformed decisions made during the selection of my primary text. Now, having been educated in basic ideas of editorial theory I wish to express the importance of the edition selection process for primary sources in a thesis. I will also consider how the genre categorization of a work can effect and limit possible interpretations by showing how one text can be interpreted under a different genre. Finally I will propose a possible edition for the primary text that could serve the purpose of a thesis better, if such an edition existed.

Being new to editorial theory, I began writing my Honors thesis on the topic of gender and family roles in Wilkie Collins's The Woman in White. I only thought about its editorial history because I was interested in the serialization of the original work. Beyond my knowledge 
of the original serialized format published in Charles Dickens's popular magazine, All the Year Round (AYR), from November 26, 1859, to its 40th and final installation on August 25, 1860, I did not consider the changes to the text that had occurred since the 40th installation, 154 years ago (Peters xxxii). Since my study of the editorial history of The Woman in White I realize the importance of selecting a certain edition for my Honors thesis. This ultimately altered my course of study from a general literary analysis of gender and family roles to a study of selecting editions for thesis writing as well as how the genre categorization and theory used to analyze a text can effect or limit the interpretation of the text. The central portion of my thesis still contains the original plan of looking at gender and family roles in The Woman in White, but the original intentions of the thesis have changed from being the focal point of the thesis to being an example of some of the problems caused by genre classification.

\section{Introduction: Possible Consequences of Not Considering the Edition of a Text}

As with any popular work of fiction, The Woman in White has never been out of print (Cauti xxxi). The result of a book never having gone out of print is the number of editions are so numerous that finding an appropriate edition for the purposes of academic research becomes difficult. Unlike books in other eras of literature, Wilkie Collins's The Woman in White comes from an era where most works were first published in a serialized format and then changed into book form if the serialized version was a success. Some other examples of famous works that were serializations include the collection of Sherlock Holmes stories published intermittently in 
The Strand magazine from July 1891 to January of 1905 by Sir Arthur Conan Doyle, as well as

Collins's other famous work, The Moonstone published in AYR during the year of 1868

(Connolly xiii). In the case of The Woman in White, a sensational novel with multiple narrators, proclaimed to be the first of its kind by many scholars, ${ }^{1}$ it was immediately popular and thus published in book form following its final serialized installment.

Originally uninformed of the importance of choosing an edition, the Barnes \& Noble Classics (BNC) edition, published in 2005, was the original edition chosen for the purposes of this thesis. The publication page of the BNC edition states, "The present text is that of the corrected, 'New Edition' of 1861" [sic] (iv). Uniform to its kind, the BNC edition contains a timeline of the author's life, an introduction written by a scholar, endnotes, other works inspired by the classic, and a "Comments \& Questions" section. This edition was initially selected for the research process simply because it was the edition given as a gift, thus originally read for pleasure, not as the primary subject for a thesis. Once the BNC edition had been read and The Woman in White determined to be the text of analysis for the thesis, the BNC edition was replaced by a different edition.

Initially chosen to be used in the writing of the thesis as a means for copying direct quotes from the text, the selection of a second edition was determined based on the editions commonly selected by professors in the Honors College- Oxford World Classics (OWC). Indicated before the novel's commencement, though not noted on the publication page, the OWC edition, reissued from its first 1996 publication in 2008, later states "this edition uses the 1861 'New Edition' text, with significant variants between it and the version serialized in All the Year

\footnotetext{
1 The opposing view says Lady Audley's Secret by Mary Elizabeth Braddon is the first true sensational novel as it was published closer to the wave of other sensational novels, in 1862. More information on the topic of genre will be presented later on.
} 
Round" (xxv). Unlike the BNC edition, the OWC edition does not note the dates of any of the original editions on the publication page but notes the information listed above on a separate page titled "Note on the Text." Though still a classics edition, as opposed to a scholarly edition, OWC editions tend to have more supplemental materials than BNC editions. For example, the OWC edition indicates where different serializations of the original text began, ended, as well as information on the exact date of its serialized edition—information one would want to document in the event of writing a thesis.

Now having become more aware of the importance of selecting a text, an entirely different edition and format has been chosen as the primary source for this thesis. The edition that has been selected as the text from which to quote is a facsimile, or photographic archive, of the original serialized edition from $A Y R$. After learning all the different types of editions that can be produced based on different editorial theories and methods, it is my belief that a facsimile version of The Woman in White best suits the needs of a thesis. As writing a thesis takes a great amount of time in both the writing, but especially the research process, it can be argued that the supplemental information and notes that come with scholarly or classic editions, known in editorial theory as "paritexts" (Genette 2), are not needed as the information is found during the research process. ${ }^{2}$ However, in order to explain the reasoning behind the choice of a facsimile edition as the desired edition for a thesis, the editorial history of The Woman in White must be given.

\footnotetext{
${ }^{2}$ In the case of my senior thesis I have already read an edition of The Woman in White that had supplemental information, thus my need for the primary source at this point is based on the need for quoting the text, which can be done by using a facsimile edition.
} 


\section{The Editorial History of The Woman in White}

Collins first met Charles Dickens while working as a journalist under Dickens's supervision in 1851 (Sutherland 648). In addition to this Collins contributed to Dickens's periodical Household Words in which he published various short stories including "Sister Rose" and the collection of short stories called After Dark (Cauti xx; Heller 82). "Collins and Dickens became close friends who shared an interest not only in literature but also travel, amateur theatricals, and the opposite sex" (xx-xxi), writes Camille Cauti in her introduction to the BNC edition. In April of 1859 Dickens began the publication of the literary journal $A Y R$ (Sutherland 648). On November 26, 1859, the first serialization of The Woman in White appeared beside and immediately followed the conclusion of A Tale of Two Cities (Cauti xv) (Appendix A). At the same time Collins's novel was published in the United States in Harper's Weekly from November 25, 1859, to August 4, 1960 (Cauti xv). Other works that were first published in $A Y R$ include Great Expectations by Dickens, and The Moonstone, also by Collins (Cauti xv-xxxiii). To establish clarity in the difference between the manuscript (MS), the serialized edition, the 1860 edition, and the 1861 "New Edition", the editorial history of the text will be introduced in a chronological manner.

Beginning with the 490-page manuscript that still exists today, held at the Pierpont Morgan Library in New York, it is important to take into account the substantial changes made between the MS and the serialized edition (Sutherland 648-649). At the start of his MS Collins gives detailed information on the composition and publication of The Woman in White including his whereabouts in London, such as building names and addresses, at the time he was writing the 
manuscript (Sutherland 647). The form in which he wrote this briefing is written in such a way that suggests it was written for personal information and cataloging rather than for a public audience. The complete text of this cataloging is not included in the BNC or OWC editions but has been included in other editions of the work. In addition to this, it can be seen in the MS that Collins already had plans to publish the serialized novel in a three volume format, as after what was to become the 11th and 26th serialization he wrote a note for the printer stating "End of Vol 1 (in three vol edition)" (Sutherland 678). While this appears to be Collins's intention, choosing to change the format of the work would alter things such as moments of suspense caused by finishing a serialization and having to wait for the next number to come out.

Moving on to the serialized edition of the text, the changes made between the MS and the serialized edition, which appeared in AYR from November 26, 1859, to August 25, 1860, were few. However, one substantial change is that in the MS Sir Percival Glyde marries Laura Farlie after her twenty-first birthday where as in the serialized edition he marries her before. This was most likely because Collins wanted Glyde to appear more suspicious of where the inheritance would fall and secure his right to her fortune before she herself would be the sole owner (Sutherland 652). One noteworthy difference between the serialized edition and later editions is that the serialized edition has no formal preface but rather the first five paragraphs are set apart from the rest of Chapter One with a line as well as a title, "Preamble," that does not appear in either the BNC or OWC edition (Appendix A). As noted before, the serialized edition was simultaneously published in Harper's Weekly in the United States but there are no substantive differences between the serialized edition in AYR and Harper's (Sucksmith xxiv). 
Following the serialization of The Woman in White, a three-volume edition of the novel was published in 1860 in both Britain and the United States, resulting in its first major editorial transition. In the three-volume edition of the text Collins wrote a preface that boasts the popularity and uniqueness of his text as the first novel of its kind with multiple narrators as well as a suspenseful plot. While the BNC edition leaves room for this boastful preface at the front of the book (5), the OWC edition presents the 1860 preface after the story (644). While both editions choose to include the 1860 preface within the binding of their texts, the placement of the 1860 preface within the physical book in relation to the story is different. In the preface Collins notes the kinds of changes that were made in the revision process: "I have only to say that it has been carefully revised; and that the divisions of the chapters, and other minor matters of the same sort, have been altered here and there, with a view to smoothing and consolidating the story in its course through these volumes" (645). Aside from the addition of this preface as well as the changes noted by Collins here, substantial changes to the written work were not made. However, as mentioned in the description of the MS, the work was divided into three editions by splitting the serializations into three parts: Numbers 1-11 for the first volume, Numbers 12-26 for the second volume, and Numbers 27-40 for the third (Sutherland 669-702). Not only was the serialization split into three parts but the divisions of chapters in relation to the original serialized work changed (Appendix E).

Lastly, the final edition of the work published in Collins's lifetime, known as the "New Edition," published in 1861, is the edition most commonly used as the copy-text for more recent editions. According to Harvey P Sucksmith, "the Reverside edition, ed. Kathleen Tillotson and Anthea Todd, 1969, uses AYR as its [copy-text] but adopts the corrections in the chronology 
made in the 60 and 61 " (xxiv), but this is the only recorded modern edition to have done this. The reason for this is that major chronological issues made in the first serialized publication were not addressed until the "New Edition." As this story has a complex narrative structure and takes place over a long period of time, 1849-1852, chronological issues were easy to make but also picked up by reviewers. After reviewer E.S. Dallas of The Times pointed out chronological issues in his review of the three-volume 1860 edition of The Woman in White on October 30, 1860, Collins wrote to his publisher the next day asking him not to print any more copies of the threevolume 1860 edition until revisions were made, thus producing the start of the 1861 "New Edition" (Sutherland 662). In the letter to his publisher, Edward Marston, written on October 31, 1860, immediately following Dallas's review, he writes:

The critic in the Times is (between ourselves) right about the mistake in the time. Shakespear has made worse mistakes - that is one comfort. And readers are not critics, who test an emotional book by the base rules of arithmetic - which is a second consolidation. Nevertheless we will set the mistake right at the first opportunity [sic]. (Baker 191)

Even if Collins did not think his readers would search for the same mistakes that reviewers like Dallas had, it jostled Collins's pride enough for him to create the revised "New Edition" as can be seen in the excerpt from this letter. This private letter was not exposed in public, but in the 1861 preface he wrote to his readers a similar message, this time truer in words, to that of the 1860 preface acknowledging previous mistakes: "I have endeavoured, by careful correction and revision, to make my story as worthy as I could of a continuance of the public approval. Certain technical errors which had escaped me while I was writing the book are here rectified" (OWC 3). 
Collins goes on to assure the public that he ran all the legal material in the plot by a lawyer to ensure that all legal maters matched the practices of the Victorian British Empire. As Collins initially intended The Woman in White to be a three volume novel, he preserved this quality by dividing the novel into three "Epochs" which reflect the exact breaks in each of the volumes from the 1860 edition (Sutherland 678). Note that chapter breaks remain the same (Appendix E).

It is relevant to emphasize that both the BNC edition and the OWC edition use the 1861 "New Edition" as the copy text. The first reason for this is likely to do with the fact that Collins had not completed the story and thus had insufficient time to edit before publications began. The second reason had to do with the serious chronological issues that remained present until the "New Edition" (Cauti xix). As the serialized version in AYR is the first edition of the work, and a three-volume edition was published in both Britain and the United States immediately following the completion of the serialized form, the "New Edition" is technically the third edition (Cauti xxii). Though both classic editions use the "New Edition" as their copy text, the OWC edition places asterisks to indicate where significant changes are made from the MS, though there are few (Sutherland 649).

\section{A Facsimile as the Best Option for this Thesis}

The editorial history of this text is more complex than most, but for different reasons than most other texts with complex editorial histories. The cause for such complexity, as stated before, is because of the time constraints which Collins was working within when composing the serialized version. Chronological flaws in the text could not be given proper attention until the

"New Edition." The reason for choosing the facsimile of the serialized edition for the purposes of 
academic research, easily found on online archives such as Project Gutenburg, is because it is important to be aware of the original form in which the original audience first experienced the text. Sucksmith writes inline with this idea that using $A Y R$ as the copy-text follows "the original spirit of the novel which was conceived and written as a serial even though Collins eventually intended to publish it in volume form" (xxv). Though Collins did intend to eventually publish The Woman in White as a three volume form, part of the "original spirit", as Sucksmith referred to it, was the suspense of having to wait an entire week to read the next serialization if you were a subscriber to $A Y R$. The suspense of having the work split into serializations not only created much of the spirit of the novel but also influenced the interpretation of genre of the novel as a sensation and mystery novel. Reading a facsimile version of the original serialization, such as those found on online archives, allows the modern day reader to pick up on moments of suspense that were removed in the creation of the three volume edition that combined serializations into the same chapter. This is to say that the breaks of the serializations do not match the breaks of the chapters of the 1860 edition and 1861 "New Edition"(Appendix E). This in affect alters moments of suspense as some of the serialization, as can be in Appendix E, have been divided into two chapters or crammed into one.

\section{Edition and Classification of Genre}

Up until the arrival of Queer Theory in the 1990s and queer literature writers assigned characters traditional gender and family roles. However, throughout various canons before the late 20th century there were authors who experimented with gender and family roles that were considered "different". The Woman in White tests the boundaries of gender and family roles as 
half sisters Marian Halcombe and Laura Farlie display a relationship that is a blend of sisterly companionship and erotic desire. This is to say that not only was Collins testing the limits of genre but characterization as well. Both left without parents in the care of their wealthy but invalid uncle, Frederick Farlie, the two unmarried sisters turn to one another for emotional support in such a way that a homosocial relationship manifests. Along with this erotic relationship, and their invalid uncle, a variety of other strange characters who test gender and family norms appear. As Collins's popular Victorian novel introduced so many characters that broke traditional gender and family roles, a connection can be made between these characters and the fact that The Woman in White was the first of a new genre of literature known as the sensation novel. Though there is no direct link between the evolution of Queer Theory and queer literature to The Woman in White, many of the theories and themes that appear in these 20 and 21 st century genres are applicable to the characters and relations in The Woman in White meaning the genre of queer literature and theories of Queer Theory manifested much earlier than is currently accepted. This realization begins to show how limiting a text by a categorization of genre is negative.

Genres were created for the purpose of being able to categorize a text, but as is the case with any categorization, this action limits the way the text can be interpreted and analyzed. If one were to pick up either the BNC or OWC edition and simply read the information on the back cover, the words written by the publishers would no doubt brush the surface of genre and begin to create expectations for the reader. Genres are generally mentioned on back covers so that book store owners can get an idea of where to place to book which in affect influences which kinds of readers pick up the book. However, in the case of writing a thesis paper the purpose of a primary 
source is to establish new thoughts, not to begin limiting options based on words on the back cover of a text. This further establishes the benefit of using a facsimile edition for the primary source. If the reader were to pick up a facsimile edition of the text there would be no words in reference to genre aside from hints and clues within the work itself.

In his book Paratexts: Thresholds of Interpretation, Gérard Genette talks about the concept of "paratext". Paratexts are all of the things that are not part of the written work itself. One could extend paratext to include the way the story has been formatted on the page, thus making the idea of a story the only non-paratext part of a physical publication. Genette divides this idea into two parts. The first of these two is "paritext" which is all of the physical parts of a book that are not part of the story itself. This includes things like a photo of the author on the back cover, an introduction by an academic, the dedication page, and summaries and other notes on the back cover. The second part of paratext is "epitext", which will not be discussed, but is all the things that are related to a specific work but are not part of the work itself such as interviews with the author, the author's blog, and book reviews. In his introduction Genette writes:

The paratext is what enables a text to become a book and to be offered as such to its readers and, more generally, to the public. More than a boundary or a sealed border, the paratext is, rather, a threshold .... that offers the world at large the possibility of either stepping inside or turning back". (1-2)

While paratext is not something that the reader consciously thinks about while choosing a book to read, it is definitely something that takes part in the decision process. The same is true for when a researcher is considering how to approach a text. This concept of paratext helps to 
explain why a facsimile edition of The Woman in White would be the best option in the case of conducting research and analyzing a text.

Looking at the back cover of the BNC edition, various statements on the back cover's summary begin to influence the reader's mind on what they are about to read: "One of the greatest mystery thrillers ever written, Wilkie Collins's The Woman in White was a phenomenal best seller in the 1860s, achieving even greater success that works by Dickens, Collins friends and mentor" (back cover). With this introductory sentence the possible reader is already under the impression that what they will be reading is a "mystery thriller". As will be explored later on, categorizing Collins's work as a mystery thriller causes limitations on personal interpretation.

On the back cover of the second text, the OWC edition, there is a similar use of genre categorization written by the publishers that limits the possibilities of interpretation. More briefly stated than the BNC edition, the first sentence takes a declarative form: "The Woman in White (1859-60) is the first and greatest 'Sensation Novel'" (back cover). Taking it one step further than the $\mathrm{BNC}$ edition, the $\mathrm{OWC}$ decides to go as far as to put quotations around and capitalize the assigned genre, solidifying in the possible reader's mind that they will be reading "the greatest 'Sensation Novel'".

As can be seen here, the paritext on the backs of the BNC and OWC editions limit the way in which a possible reader or thesis writer could interpret the text. Beyond this, these two editions propose to their readers that they will be reading two different genres. As the genre of mystery is already quite common and understood, a look at the ways in which a text can be interpreted under the genre categorization of a sensation novel will follow, however, the benefits of a non-biased format of a facsimile that does not propose possible genres for a text is evident. 


\section{The Sensation Novel}

The genre of the sensation novel, which was first recognized in the 1860s in Victorian England, explored and represented the conflict between the ridged society of the time and the rapidly changing societal and gender roles that came in response to the industrialization boom in England in the United States. Sensation novels have been limited and defined as novels containing a mix of predictable and unexpected elements representing and reflecting the taboos, anxieties, and fears of these transitions that began with capitalization and urbanization (Dewsbury 219). Many scholars also claim that sensation novels as well as the appearance of detective and mystery manifested from shocking murders and crimes that Victorians read about in the papers (Dewsbury 220). As odd as it may sound to someone living in the 21 st century, Scotland Yard and the idea of a basic police force to control crime did not appear until the Victorian Era and forensics was just at its preliminary stages (Collins). However it is important to note that The Woman in White is not a detective novel as it lacks the basic elements of a detective novel - a detective, an incompetent police force, and at least two suspects (Collins). The Woman in White is can be categorized as a mystery novel, however, as the BNC edition did, as there is suspense, criminal activity, and secrets.

Women had very few rights at the time when sensation novels began to appear, but these novels reflected a new Victorian female that did not match the traditional expectations of being "pure, pleasant, and supportive of men at all times" (219). According to Literary Criticism Online's article "The Sensation Novel", a sensation novel contains elements including "Corpses, secrets, adultery, insanity, prostitution .... [that] are designed to make the reader feel basic sensations — shock, disbelief, horror, suspense, sexual excitement, and fear" (219). Inline with 
the elements of a sensation novel, The Woman in White produces such emotions as two men plan to steal a woman's inheritance, identities are switched, and poisons are distributed. Key elements of sensation novels when applied to characters and character relations produce personalities and interactions that come to show how The Woman in White can be analyzed or read under late 20th century Queer Theory. This in turn shows the connections between sensation novels and queer literature. In the same way that sensation novels explored social and gender role changes in society, the later genres embraced by queer theorists explore these same changes that produce altered interaction between characters compared to previous genres that stuck to social and gender norms. As The Woman in White can be analyzed under Queer Theory and be considered queer literature, the issues and limitations with classifying this novel as a "mystery thriller"(BNC) or the "greatest 'Sensation Novel"” (OWC) begin to surface.

\section{Is The Woman in White a Sensation Novel?}

Whether Collins's novel takes the form of a sensation novel or not has been a heated topic between literary critics and theorists alike. So for the OWC edition to assert the novel's genre on its back cover in the way that it did is quite a statement. The reason for the conflict is rooted in the fact that if it is indeed a sensation novel it would be the first of its kind, beginning serialization in 1859. Two years after The Woman in White was published Mary E. Braddon's very successful novel, Lady Audley's Secret (1862), was published and often takes the claim as being the first sensation novel (Dewsbury 220). Part of the reason for this conflict is that male and female authors were often split in literary analysis in the Victorian Era, thus the genre of sensation written by men was seen as completely different from that of women. For the most part 
male sensation writers included much more detective and crime fiction while female sensation writers often had female protagonists. Collins is often considered an exception to this streamline gender categorization because of the number of strong female characters, and even heroines, he includes in his work such as The Woman in White's Marian Halcombe (Dewsbury 219).

The confusion over whether to place Collins with the female or male sensationalists was very much rooted in the struggle of many Victorian authors of the time as the distinction between "popular" and "serious" fiction in the literary marketplace began to grow. Tamar Heller writes in her book Dead Secrets that "the difference between popular and serious is defined most obviously in class terms — "high" and "low"- but also in gendered terms, contrasting masculine professional ethos with sensation fiction identified as feminine" (83). Collins desired to be identified with the more serious male side of sensation writing but because of his many strong female characters this was hard for many of his male contemporaries to accept him in their discourse. In Julia Swindells's book Victorian Writing and Working Women she writes that the literary world during the Victorian age was male dominated and male defined, the only female writers to succeed, such as George Eliot and the Brontës, were those writing under male pseudonyms. Despite Collins having the benefit of being a male, whether to classify him under popular or serious fiction was still an issue.

Just like all authors, Collins too has sustained being jostled around in various limiting genre categorization even years after his death. As stated before, assigning books or authors to various genres is limiting when it comes to analyzing and interpreting a text. It is here that I begin to propose The Woman in White as queer literature in order to show how eliminating and 
ignoring the classification of genre can result in a new and diverse means of interpretation for research.

\section{Reading Queerly/Queer Reading}

The relationships between characters in queer literature are relations that stray from the social norms of the time and place the work is created. The term "reading queerly/queer reading" can not be identified as one thing or easily defined. The author's choice to stray from social norms often causes relations between related and non-related characters that challenge the gender and family roles of that society, most visible when one is reading queerly. Reading The Woman White queerly, the reader is able to observe the intricacies of unique relationships of the characters in the story as well as the actions and personalities of the characters themselves that challenge the gender and family roles of the Victorian Era. It is important to note that Queer Theory, the discourse from which reading queerly manifests, is a late 20th century American theory. Thus, I am stretching this discourse to Victorian England and to show how The Woman in White fits in both the genres of queer literature and the sensation novel, thus showing the limitations of naming the genre. This Victorian novel is not currently accepted as queer literature, but I hope that through a series of close readings and character analyses from The Woman in White that the possibility of Collins's book to be interpreted under a different genre will show the limitations of such editions as BNC and OWC in comparison to a facsimile edition. 


\section{Forming Connections Between the Sensation Novel and Queer Theory}

Before diving into the various opportunities The Woman in White could have if it were interpreted under Queer Theory it is important to mention the historic division between what is accepted as queer literature and what is not. The monumental moment that would forever change not just literature, but society itself was the 1895 trial of Oscar Wilde ${ }^{3}$. The details of this trial will not be examined closely but it was in this trial that the prospects, ideas, and fears surrounding homosexuality first appeared. Ten years before the trial took place, an 11 th section of the Criminal Law Amendment Act of 1885 was added which had to do with the then criminal offense of homosexual acts (Humphreys 5). But it was Wilde's trial rather than the amendment that brought much attention to the subject. Before this trial though homosexuality- and heterosexuality - existed, naturally, there was no name for it. As this concept did not exist, it was far more common for both men and women to have much closer relations, including the physical, between one another without their ever being a question or suspicion of something beyond friendship. However, as stated before, the relationship between Halcombe and Farlie is such that the possibility that Collins intended the relation to be an erotic one is still valid, but it is because of this historical division of the trial that The Woman in White is not more often given the opportunity to be analyzed from a queer perspective.

\section{The Victorian Family}

Now, to transition back into the issues surrounding genre classification by exploring the possibilities of The Woman in White as queer literature beginning with the differences between

\footnotetext{
${ }^{3}$ For further information on the trial itself see Trials of Oscar Wilde from the Notable British Trials Series, edited by H. Montgomery Hyde.
} 
British families of the time and the one presented in this novel. Leila May begins her article by questioning the use of language at the beginning of Wilkie Collins's The Woman in White. The primary narrator, Hartright, introduces the novel as being a "strange family story", May questions if perhaps he means "a story of a strange family" or "a story of the strangeness of the family" (82). With the only male presence being represented by Uncle Frederick Farlie, who identifies himself as an "invalid" (43) it is no wonder that there is an absence of a nucleus family. Despite the absence of a clear nuclear family in The Woman in White, the various character's attempts to replace it by embodying the role of multiple family members is clear. May explains in "Sensational Sisters: Wilkie Collins's The Woman in White", that in Victorian England the nuclear family was very important and the most important component of the family were the female relations (82). Collins choses to focus his attentions on the natural sisterly love between Farlie and Halcombe, yet, the love and attention they give one another reaches beyond sisterly love making the term "sisterly love" express far less emotional, and perhaps sexual, desire then is present. May changes the more reserved term of sisterly love to "sororal desire" (82) as the relationship of the sisters is that of a sensation novel, as well as, I argue, typical of queer literature. It is important to emphasize that Halcombe and Farlie share the same mother and that they are only half-sisters (Appendix B).

\section{Halcombe and Farlie's Sororal Desire}

In Eve Sedgwick’s article "Across Gender, Across Sexuality: Willa Cather and Others" she quotes Gayle Rubin's “Think Sex” that theorizes a difference between gender and sex: "Feminism is the theory of gender oppression .... Gender affects the operation of the sexual 
system, and the sexual system has had gender-specific manifestations. But although sex and gender are related, they are not the same thing" (Sedgwick 53). This observation of gender being related yet different from sex resonates throughout many works such as Shakespeare's "The Merchant of Venice", James Joyce's Portrait of the Artist as a Young Man, and of course, as indicated in the title of this particular article by Sedgwick, the works of Willa Cather. As for the British literary canon, in this case observing the Victorian Era, 1837-1901, this idea of gender being different from sex appears in The Woman in White. Highly driven by the masculinized Marian Halcombe, but equally driven by her fragile and feminine sister as well, gender and family roles between these two characters are blurred as their relation is neither of romantic or sisterly love, but rather a hybrid that enacts Sedgwick's theory of "homosocial desire" (2). As mentioned before, the terms "homosexuality" and "heterosexuality" did not exist as common language prior to the Oscar Wilde trials, but the relevance of these modern terms are no doubt applicable to Collins's Victorian masterpiece.

In Sedgwick's Between Men: English Literature and Male Homosocial Desire, the discussion of male relationships in mid-eighteenth to mid-nineteenth century literature can be applied to Halcombe and Farlie's relationship, between women. Having no father or mother in their home Halcombe's asserts herself as the masculine figure to compensate for the absence of a masculine figure in Limmeridge House as she is the more emotionally secure and strong. It is not only psychologically that she replaces her sister's uncle (Appendix B) as the man of the house, but her physical appearance compliments her masculine behavior as described by Hartright. Though one of the major characters in the novel, Halcombe is not introduced to the reader until 
the second installment of The Woman in White (Appendix D) and does not become the narrator of the story until the tenth installment (Appendix C) - already well into the mystery.

In Hartright's first encounter with Halcombe he comes upon her in the breakfast room where she is gazing out the windows into the gardens. As the light is coming through the windows Hartright is only able to see the silhouette of Halcombe, which at first appears feminine. Hartright watches as his hostess turns and approaches only to be shocked and nearly horrified by Halcombe's very masculine face that belongs to her feminine figure:

She left the window - and I said to myself, The lady is dark. She moved forward a few steps - and I said to myself, The lady is young. She approached nearerand I said to myself (with a sense of surprise which words fail me to express), The lady is ugly! (AYR Number 2, page 118)

While Hartright is able to identify "the rare beauty of her form" (118), he has a prescribed image of what a beautiful woman should look like, and when the light in the room falls upon her face he immediately rejects it. According to Elana Gomel's article "The Tell-Tale Surface; Fashion and Gender in The Woman in White", the clothing choices for Halcombe's character are equally intentional to the body figure given to her. Gomel describes Halcombe's body as being a “gender-deviant body". As seen from Hartright's first encounter with Halcombe, her figure from afar resembles the perfect female, only to be juxtaposed up close by a masculine face. Hartright thinks: "The lady's complexion was almost swarthy, and the dark down on her upper lip was almost a moustache. She had a large, firm, masculine mouth and jaw; prominent, piercing, resolute brown eyes; and thick, coal-black hair, growing unusually low down on her forehead" (118). This description from a male perspective, both narrator and author, is critical yet 
even a female author or narrator may have provided a similar description. Collins never provides the reader a description of Halcombe from the perspective of Farlie, but the sisters' interactions with one another, as will be seen in the next section, give us evidence enough that Farlie is drawn to her sister both physically and psychologically. As can be seen from this analysis alone, if the text is limited by the labeling of genre of sensation or mystery the possibility of it being interpreted under Queer Theory lessens.

\section{Sensation and Queer Revelations in Marian's Diary}

Following the narration of Hartright and Vincent Gilmore, Halcombe takes on the narration at the end of the "First Epoch" with the 10th installation of The Woman in White (Appendix D). Halcombe's narrative is different in that it takes the format of a diary. Rather than composing her thoughts at a time following the experience, her feelings on the paper are exact to what they were on the day of each experience. Of course the work is fiction, but in the writing of diaries immediacy is assumed.

When the author chooses to publish in the format of a diary, whether fiction or nonfiction, it is often because they are experiencing extreme emotions - such as those produced when reading a sensational novel — that cannot be described after that moment of extreme emotion, whether is be depression, pleasure or happiness. Halcombe chooses to take the form of a diary because of the fluctuation of emotions she feels as the mystery continues and the danger that her sister is in increases. As Halcombe is extremely emotional she is unable to articulate her feelings at a later time and thus gives her part of the narrative in diary format. As described in Roy Pascal's Design and Truth in Autobiography, the main difference between an autobiography and 
a diary is that in a diary the author "moves through a series of moment in time ... the diarist notes down what at that moment seems of importance to him: its ultimate long-range significance cannot be assessed" (3). The fact that the long range significance of Halcombe's writing cannot be assessed not only adds to its sensational components as a mystery novel, that is both the narrator and the reader do not know what the future will bring, but it also gives us the opportunity to view Halcombe thoughts and feelings towards her sister. This is extremely important in identifying the both the elements of the sensation novel as well as queer literature within The Woman in White.

According to Halcombe's diary, while still in the company of her sister, a description of the interaction between Halcombe and Farlie resembles that of lovers rather than sisters as Halcombe attempts to comfort her half-sister. This act of comfort reveals the presence of sororal desire in the novel as it alludes to physical desire. As the sisters discuss how to go about dealing with Farlie's marriage, the sororal desire appears through physical actions:

She put her arms round my neck, and rested her head quietly on my bosom. On the opposite wall hung the miniature portrait of her father. I bent over her, and saw that she was looking at it while her head lay on my breast. . . . she stopped, turned her face to me, and laid her cheek close against mine. . . She put her lips to mine, and kissed me. (AYR Number 10, page 309-310)

These interactions between the sisters suggest that sororal desire is a true emotion expressed between them. These are not the "normal" interactions between two sisters but rather that of two lovers - Halcombe taking on the role of the male as the comforter and Farlie the female role of the comforted. In this interaction the presence of Farlie's father on the wall is only solidifies 
May's comment of this being "a story of a strange family". The introduction of "The Sensational Novel" from Literary Criticism Online states that "women refrain from expressing themselves openly in the presence of men" (219). As can be seen from this excerpt, Halcombe is at ease in expressing her feelings towards her sister in the absence of men. Perhaps the close relationship between the sisters is also due to the fact that women in this era were not permitted to express themselves openly in front of men. Farlie's father's portrait is present as his daughter and stepdaughter caress but he cannot comfort them. The fact that Halcombe is also replacing a missing masculine parental and protective figure as well as filling the role of a lover yet again shows how reading The Woman in White queerly can reveal much more to the text than limiting one's self by a certain genre.

\section{The Erotic Triangle}

With the arrival of Walter Hartright, the first narrator, at Limmeridge House, Halcombe and Farlie's homosocial relationship is disrupted by this new figure creating an "erotic triangle" (16). This is to say that the relationship between Halcombe and Farlie retains its elements of sororal desire but then adds Hartright to create a triangle of interest and desire between the three. The presence of an erotic triangle in a sensation novel attests to the links between this genre and the genre of queer literature. Sedgwick, a prominent figure in the discourse of Queer Theory, describes in the first chapter of Between Men, "Gender Asymmetry and Erotic Triangles", these erotic triangles as happening when a women comes between the relationship of two men. Of course this same concept is not limited by sex or gender and can be applied to various circumstances, such as that of Halcombe, Farlie, and Hartright. In this erotic 
triangle, Farlie, though extremely feminine in her appearance and demeanor, is perhaps the figure with the most power in the triangle. It is she who has an erotic relationship with both her half sister and Hartright. Sedgwick uses the term desire rather than love as she sees love as being used to describe a particular emotion while desire is a structure (2). Though Halcombe and Hartright are like brother and sister and care about the other very much the word "erotic" would ill describe their relationship. With both masculine characters, Halcombe and Hartright, having erotic desire for Farlie, it can be said that on a gender level, Farlie is the woman "between men". To enhance this erotic triangle Halcombe expresses to Hartright that the three of them must live with one another. "'After all that we have suffered together', she said, 'there can be no parting between us, till the last parting of all. My heart and my happiness, Walter, are with Laura and you'"( ). It is later in the novel that this wish comes true. As can be seen, Sedgwick's theory of the erotic triangle, which she uses to analyze queer texts such as the works of Cather, is present in this Victorian, pre-Wilde trial novel.

\section{Mr. Farlie as a Queer Character}

To further establish the claim of The Woman in White as a queer text the presence of another queer figure must be elaborated upon. Upon arriving at Limmeridge Hartright's first encounter is not with the male of the mansion, as is often the case (aside from the butler), but rather Hartright is welcomed by Halcombe, not even a blood relative of Mr. Farlie, but rather the daughter of his sister-in-law who had an affair with a Mr. Halcombe (Appendix B). Considering blood line implications of honor that were present in the Victorian Age this is quite the decision on Collins's part. As Mr. Farlie does not take on his role as the head of the house, the next best 
candidate in the field of masculinity, who happens to be Halcombe, takes on the position. It is claimed here that she would be the next best person to receive a newcomer as there are no other male characters of importance and she is the most masculine female.

The first encounter with Mr. Farlie, the master of Limmeridge, as described by Hartright who was hired to be the drawing master for Mr. Farlie's niece and step-niece notes Mr. Farlie's feminine qualities beginning with the physical observation of his delicate body:

His beardless face was thin, worn, and transparently pale ... . His feet were effeminately small, and were clad in buff-coloured silk stockings, and little womanish bronze-leather slippers. Two rings adorned his white delicate hands. .. . Upon the whole, he had a frail, languidly-fretful, over-refined looksomething singularly and unpleasantly delicate in its association with a man, and, at the same time, something which could by no possibility have looked natural and appropriate if it had been transferred to the personal appearance of a woman. (AYR Number 2, page 121)

Mr. Farlie's feminine appearance contrasts with Halcombe's masculinity which adds to May's presumption about this being "a story of a strange family", or perhaps as Queer Theorists may label it, a queer family. As mentioned earlier, it was not Mr. Farlie who was the first to greet Hartright, but Halcombe. Implied by the order of introductions and the character description of Mr. Farlie it can be stated that Collins did not intend him to be the center or head of this particular Victorian family. The reader is introduced to both Halcombe and Mr. Farlie in number 2 of $A Y R$ but in this particular order. If Mr. Farlie is indeed meant to be female, than the 
masculine Halcombe greeting Hartright was no doubt closer to the Victorian societal norm of the man of the house greeting guests. While the flow of inheritance goes from Mr. Farlie to his niece, possession of wealth in the family is the only thing identifying Mr. Farlie as the male head of the house in the family.

With Hartright's first encounter with Mr. Farlie it is clear that he is psychologically illsuited to run a family and such a large estate. In response to Hartright's first greetings Mr. Farlie responds by saying: "Pray excuse me. But could you contrive to speak in a lower key? In the wretched state of my nerves, loud sound of any kind are indescribable torture to me. You will pardon an invalid?" (121). Hartright was most likely using a normal tone of voice as he was warned earlier about Mr. Farlie's sensitive ears, and yet Mr. Farlie still asks him to lower his voice. Hidden away in the "deliciously soft, mysterious, and subdued" (121) atmosphere of his quarters with "a carpet over the floor, so thick and soft that it felt like piles of velvet under my feet" (121) according to Hartright, Mr. Farlie occupies himself with "rare and beautiful objects" (121) such as old coins and old drawings that he likes to restore. Hartright provides the reader with a description of the master's quarters and the master himself before their first conversation begins. By choosing to narrate in this order Collins ensures that he is in control of forming an opinion of Mr. Farlie for the reader rather than the reader being able to interpret Mr. Farlie's character on their own. This is to say that before the reader has the opportunity to read Mr. Farlie's narrative and get to know him personally, they must sustain a third person description from another character's narrative (Appendix C). Using feminine descriptors assures that Mr. Farlie will be read as a feminine character in the same way that Halcombe is read as a masculine character. Even from this first interaction between Hartright and Mr. Farlie it is clear 
to both Hartright and the reader that there is no traditional head of house since Mr. Farlie never leaves his quarters and has his personal servant deliver all messages to different parts of the house rather than speaking to people in person.

\section{Conclusion on interpreting The Woman in White as Queer Literature}

As discovered in this brief analysis that displayed the possibilities of The Woman in White as queer theory, it can be seen why the paratext of edition such as the BNC and OWC edition limit the reader in many ways. Of course the novel can be read as a "mystery thriller"(BNC) or "Sensation Novel”(OWC), but to restrict possible interpretation by labeling the book such is limiting for both a lay reader and a research writer. As preposed earlier, a facsimile of The Woman in White would preserve the original "spirit of the text" as well as eliminate limiting paratext found in newer editions of the text. Without the additional paratext the reader could possibly open the book and recognize the possibility of the text as queer literature with the presence of a queer family, queer characters, sororal desire, and erotic triangles. However, as stated before, because this Victorian novel was written before the Oscar Wilde trials it is immediately rejected as being categorized as queer literature since the presence of homosexuality and heterosexuality was not yet named and known.

\section{Proposing a New Edition}

Though the facsimile from $A Y R$ is being used for the purposes of citing the primary source of this thesis, if a reader was simply choosing to pick up the book for pleasure, or they were interested in a bit of the history behind The Woman in White, the Oxford World Classics edition would be the best option as it offers a more "reader-friendly" experience. However, 
obviously an edition that combined both the original experience of the text and enough supplemental information would be the best option.

Finding an appropriate edition of The Woman in White for the purposes of thesis research due to the complex editorial history, as can be seen from the above sections, is a complicated process. It is in the section that follows that a new edition, better suited for the purposes of thesis research, is proposed. As The Woman in White is already a lengthy serialized Victorian novel, and must take a minimum of 500 pages for just the story itself, the issue of room for commentary and notes at the front or back of the text is already at risk of being cut into insufficiently short lengths for a scholarly edition's purposes and needs. The risk of commentary and notes being cut too far comes from the cost of producing an affordable text of such lengths. It is therefore that a digital scholarly text is proposed as the ideal edition of the novel. As an advocate for digital editions of texts, Yuri Cowan says, "The audience for big expensive print editions of relatively obscure works of literature has long been limited to the libraries that could afford them or to the scholars who ferreted them out of dark corners to reveal their significance to other scholars (and ideally to their students in the humanities as well)" (223). As space is less of an issue in digital texts, this would eliminate the need to unfairly cut commentary that would be useful to scholarly needs, such as that of a thesis or dissertation. The content and format of this newly proposed scholarly digital edition of The Woman in White will be elaborated on throughout this section of the essay.

As expressed in the textual history section of this analysis, three editions of this novel were published during Collins's life causing there to be great thought into which version the scholarly reader should experience for the new digital edition of the text. As expressed by James 
McLaverty in his article "The Mode of Existence of Literary Works of Art: The Case of the 'Dunciad Variorum,"' the experience of the original design features of a text should be considered during the editorial process if design features were clearly part of the author's intent. In McLaverty’s own words he states, “The physical appearance of books sometimes has even greater importance than textual bibliographers are willing to allow it" (82). Though McLaverty is only making the argument that physical appearance should be taken into consideration if it appears the author spent time styling the appearance or changing the physical appearance to change the experience of the text, it seems as though the presentation of whatever you take to be the original form of any text, whether manuscript or first edition, should be taken into consideration for all further publications of a text. Thus, considering the original physical appearance of The Woman in White is important in the creation of this new digital scholarly edition.

With Paul Eggert's article, "Social Discourse or Authorial Agency: Bridging the Divide between Editing and Theory," the importance of honoring the original physical appearance of the text, in this case arguing for a facsimile of the serialized edition as seen in $A Y R$, can be further established. In his article Eggert discusses the difference between a text and a document surrounding issues of duplication and forgery. His direct examples are of artwork but the honoring original editions and the production of new editions come into play here as well. He gives the following definitions to clarify his case:

I instead point to a more basic distinction between text and document: "text" thought of as a human activity - the creation or, in reading, the re-creation of 
meaning_and "document" thought of as the physical level: the patterning of ink on paper which results from, or acts as the stimulus for, textual activity. (103)

In the case of The Woman in White, the text would be the idea of the story; if it were read aloud it could be said to be the meaning of the words coming from the reader's mouth. With text it is not only authorial intent that is at play but reader interpretation as well. The document would be, as stated in Eggert's definition, the patten of ink on the paper. Thus, to honor the original document, a facsimile of the serialized version of $A Y R$ would hold most true in honoring both text and document.

This brings Cowan's proposal from his chapter "Reading Material Bibliography and Digital Editions" into the discussion of a digital scholarly edition in which the original form of the text should be represented. In Cowan's chapter he proposes that photographic reproductions of the manuscript or first edition are the best way to represent a work in its entirety as numerous editions could be represented side by side without having to worry about the cost of paper (225). Cowan then makes the excellent point that, instead of creating new editions, "we are making archives rather than forming eclectic texts (226)." From Cowan's idea of photographic representations of already existing texts, and McLaverty's efforts to honor the original appearance of a text, this new digital edition of The Woman in White would be a facsimile taken from the original serialized journals from Dickens's $A Y R$.

Of course, in order to be considered a scholarly edition, this digital facsimile would need to contain other information aside from the photographic reproductions from $A Y R$, which brings the discussion to Charles L. Ross's article "The Electronic Text and the Death of the Critical Edition" from The Literary Text in the Digital Age. Though Ross, in this particular article, is also 
debating "the birth of the reader-as-editor" (225), Ross's discussion is being included in this analysis for the purpose of his discussion of hypertexts, not the reader as editor. The discussion of the effectiveness of hypertexts in digital scholarly editions begins when Ross states that the digital scholarly edition "permits readers to perform all sorts of intertextual maneuvers-linking fictional texts in an author's oeuvre, networking texts and ancillary materials (sources, annotations, commentary)" (228).

Technology has advanced infinitely since Ross's chapter was published in 1996, but his basic ideas about the possibilities that arise with the use of hypertexts are still relevant today. In this scholarly digital facsimile edition of The Woman in White there would be hypertexts to link the scholarly reader to further information. Within the text itself there would be footnote numbers placed in the same way that normal footnote numeration appear. However, rather than footnotes appearing at the bottom of the text, affecting the original experience of the text as desired by McLaverty, or as a note at the back of the text, the reader would simply click the number with their mouse or finger, depending on whether they were using a touch screen or not, and they would be taken to the corresponding hypertext. Of course the one downside of this method is that the footnote numbers would affect the originality of the facsimile, but numbers in the same font and color as the rest of the text would be less distracting than changing the color of the text to indicate when a hypertext had been inserted. After reading the hypertexts, if the reader chose to, they could easily click back and return to the text and continue reading.

This format of having hyperlinks embedded in the text is much more efficient than having notes at the end of a printed copy. When there are notes at the end of a printed copy it is harder to keep track of what note you should be reading, especially if there are multiple notes on 
one page, as is the case with both $\mathrm{BNC}$ and OWC editions of The Woman in White described in the first section of this analysis. The OWC edition is even more problematic because rather than having numbered notes, notes are indicated by asterisks, corresponding with notes in the back of the book. To find the note one has to search for the note at the back and risk losing their reading place or having to double check the page number of the asterisk multiple times. Thus, if there are multiple notes on one page it makes the process of finding out the additional information even more complicated. Having hypertexts in a digital edition, as has been proposed here, would eliminate confusion and time spent searching for the corresponding note.

To clarify the aspects of this new version of The Woman in White, here is what has been said thus far: This edition of The Woman in White would be a digital edition compatible with any electronic device that allows the viewing of eBooks (laptop, tablet, desktop, smartphone). This digital edition would be a facsimile of the original serialized form from $A Y R$, thus anything that might have been on the same page as the story would also appear in this edition (for example, the conclusion of $A$ Tale of Two Cities). Hypertexts would be indicated on the page by numbers of the same color and font as the original text. These hypertexts would lead the reader to different kinds of information about the text such as notes, commentary, historical and contextual information.

The final aspect this new digital facsimile edition would have would be a table of contents that contained hyperlinks to take the reader to supplemental readings of The Woman in White. A better way to describe this table of contents would be to compare it to the menu of a DVD. This table of contents, or menu, would allow the reader to decide whether or not they wanted to interact with supplemental materials or if they would prefer to read only the story. 
Possible things that would be included as hypertexts in the table of contents would be an introduction to the text by a scholar of Collins's work, a timeline of Collins's life, and other supplemental information and texts regarding the manifestation of The Woman in White.

The idea of The Woman in White is said to have been inspired from a variety of things including Collins's brief time spend studying law, an interesting legal case having to do with the marriage of Sir Edward Bulwer-Lytton, and his own life (Cauti xviii). In 1856 Collins visited Paris and happened to purchase a copy of Maurice Méjan's Receuil des causes célèbre. This was an account of various eighteenth century French criminal cases published in 1808 (Cauti xviii). Similar to the events of The Woman in White, one of the cases that Collins read in Receuil was about a widow who had been drugged by a family friend and admitted into a mental institution under a false name in the midst of an inheritance dispute with her brother. Though the woman from this case was ultimately able to leave the institution she was never able to regain her true name or claim her inheritance (Cauti xviii; Sutherland 651). Information such as this, in addition to a hyperlink to where you could purchase an eBook of Receuil des causes célèbre, is an example of the kinds of supplemental texts the reader could choose to engage with from the proposed table of contents.

This ideal edition of The Woman in White strikes a good balance between marketability and sound editorial theory. As far as marketability, it would be an excellent edition for scholars and students alike. In the future it is likely that all students will have access to eBooks and it will be the norm for professors to request an edition that is only offered in eBook format. Thus, while this edition may be an issue for classroom use at the moment, the expected trend shows that this sort of text would be both required and sought out. One of the major issues emphasized earlier by 
Cowan is the cost of large scholarly editions. As this edition would be a digital edition, money that would normally be spent on paper could now be used on further research and adding more supplemental materials. Thus this edition, as far as marketability, would be a success.

As far as sound editorial theory goes, those such as McLaverty and Cowan would be pleased by the dedication to preserving the originality of the reading experience by using photographic reproductions of $A Y R$. One could argue that photographic reproductions of The Woman in White in AYR already exist on the internet for free on websites such as Project Gutenburg, but what would make this edition different is the use of hypertexts which Ross would endorse as solving the issues of "the ontological tensions within the printed edition" (228). Another argument that could be made is that if photographic reproductions of the text are made then the editor does not have a job. This argument can be put to rest by Cowan's reasoning: "We are 'printing' (creating digital archives), rather than 'editing' and our primary criterion is accessibility rather than a polished, responsible scholarly text" (229). The benefit of this edition is that it would still be a responsible scholarly text, as Cowan reasoned, in that additional commentary on the text would still be provided as an option for the scholarly reader. The scholarly reader can choose to interact with the hyperlinks or simply enjoy the text in its original visual form.

Obvious biases towards editorial theory of the late 20th century have been made clear by the use of supporting texts from McLaverty, Eggert, Ross, and Cowan. The editorial theorist that would most rival the one chosen for this text would be that of Phillip Gaskell, who believed the first edition of a text should be the copy-text but that substantives should be taken from the later editions. The issue with The Woman in White is the number of editions that appeared during 
Collins's life appeared in close sequence. Gaskell would believe that substantives should be taken from the New Edition and he would not endorse using a facsimile of the serialized version even if there were hyperlinks noting the substantives. He would rather create an eclectic text that used the serialized edition from $A Y R$ as the copy text but then take substantive changes, such as edits made on the chronology, from the New Edition. Under Gaskell's theory it would be completely impossible to ever create a text that was a facsimile of the original document of any text that had multiple editions with substantial changes made during an author's life. Producers of this digital edition may be able to reason with Gaskell, however, since Gaskell believed in final authorial intent but also in the role of others in the production of a literary work.

\section{Conclusion}

As McLaverty stated: "The physical appearance of books sometimes has even greater importance than textual bibliographers are willing to allow it” (82). After providing a brief textual history of The Woman in White in the first section of this analysis, it is clear that because of the multiple editions that were produced in Collins's life that it is difficult to decide which is the edition of the text that contains "true authorial intent." Beyond this, it is clear that existing editions of The Woman in White, such as the BNC and OWC editions, do not provide and are not capable of providing a reader or researcher with adequate yet appropriate paratext that would not limit the possibilities of interpretation of the text. When genre is labeled on the back cover of a text as part of its paritext it not only informs the lay reader that they will be reading a certain genre, but also a researcher will approach a text with a closed mind. As was seen in the analysis of The Woman in White as queer literature, there are many more possibilities for this Victorian 
text than just a "mystery thriller"(BNC) or "Sensation Novel”(OWC). As page number and affordability must always be balanced with preservation of the original form of the text, it is thus that I propose a digital facsimile from $A Y R$ with hyperlinks to paratext for a new edition. As Peter Shillingburg claims in his article "How Literary Works Exist," having multiple editions of a text is fine and should be encouraged (225). Taking this claim as the final justification for creating a scholarly digital facsimile edition from $A Y R$, different editions are needed for different purposes and this edition would not only fulfill the needs of one reading The Woman in White for pleasure as they would not need to interact with the paratext, but also the needs of researchers and academics of all different levels and specialties. 


\section{Work Cited}

Baker, William, and William M. Clarke, eds. The Letters of Wilkie Collins Vol. 1 1838-1865. New York: St. Martin's Press, Inc., 1999. Print.

Cauti, Camille. Introduction. The Woman in White. By Wilkie Collins. New York: Barnes \& Nobel, Inc., 2005. xv-xxxiii. Print.

Collins, Paul. Victorian Detective Fiction. June 2012. Portland State University. Lecture. Collins, Wilkie. "The Woman in White ." All the Year Round. Ed. Charles Dickens. 26 Nov. 1859-August 1860: 40 Numbers. Project Gutenburg . Web. 9 Dec. 2013. < $\underline{\text { http:// }}$ www.gutenberg.org/ebooks/583>. . The Woman in White. New York: Barnes \& Noble Books, 2005. Print. . The Woman in White. New York: Oxford University Press, Inc., 2008. Print.

Connolly, Joy. “Introduction”. The Moonstone. By Wilkie Collins. New York: Barnes \& Noble Books, 2005. xiii-xxxiii. Print.

Cowan, Yuri. "Reading Material Bibliography and Digital Editions.". Rpt. in Editors, Scholars, and the Social Text. Ed. Darcy Cullen. Toronto, Canada: University of Toronto Press, 2012. 223-238. Print.

Doyle, Arthur C. The Original Illustrated Sherlock Holmes. New York: Castle Books. Print. Eggert, Paul. "Social Discourse or Authorial Agency: Bridging the Divide between Editing and Theory." The Editorial Gaze Mediating Texts in Literature and the Arts. Ed. Margaret Sankey. New York : 1998. 97-116. Rpt. in Comparative Literature \& Cultural Studies. Ed. Jonathan Hart. New York: Garland Publishing, Inc., 1998. Print. 
Gaskell, Philip. A New Introduction to Bibliography. New Castle, DE: Oak Knoll Press, 1972. Print.

Genette, Gerard. Paratexts: Thresholds of Interpretation. Trans. Jane E Lewin. New York: Cambridge University Press, 1987. Print.

Gomel, Elana. "The Tell-Tale Surface; Fashion and Gender in The Woman in White." Victorian Institute Journal 25 (1997): 29-58. Web. 12 May 2013.

Heller, Tamar. Dead Secrets. New York: Yale University, 1992. Print.

May, Leila S. "Sensational Sisters: Wilkie Collins's The Woman in White." Pacific Coast Philology 30.1 (1995): 82-102. JSTOR. Web. 5 May 2013.

McLaverty, James. "The Mode of Existence of Literary Works of Art: The Case of the 'Dunciad Variorum'." Studies in Bibliography 37 (1984): 82-105. Web. 7 Nov. 2013.

Pascal, Roy. Design and Truth in Autobiography. Harvard University Press, 1960. Print. Peters, Catherine. Cronology. The Woman in White. By Wilkie Collins. New York: Oxford University Press, Inc., 1993. xxvii-xxxvi. Print.

“The Sensation Novel”. Nineteenth-Century Literary Criticism 80. Ed. Suzanne Dewsbury. Detroit: Gale Group (1999): 219-330. Literary Criticism Online. Web. 28 June 2013.

Ross, Charles L. "The Electronic Text and the Death of the Critical Edition." . Rpt. in The Literary Text in the Digital Age. Ed. Richard J. Finneran. University of Michigan, 1996. 225-231. Print.

Sedgwick, Eve K. "Across Gender, Across Sexuality: Willa Cather and Others." South Atlantic Quarterly 88.1 (1989): 53-72. Gale. Web. 21 Jan. 2014. 
. Between Men: English Literature and Male Homosocial Desire. New York:

Columbia University Press, 1985. Print.

Sucksmith, Harvey P. Note on the Text. The Woman in White. By Wilkie Collins. London: Oxford University Press, 1975. xxiii-xxv. Print.

Sutherland, John. "Appendix A: Composition, Publication, and Replication”. The Woman in White. By Wilkie Collins. New York: Oxford University Press, Inc., 1996. 647-657. Print. . "Explanatory Notes". The Woman in White. By Wilkie Collins. New York: Oxford University Press, Inc., 1996. 669-702. Print.

Swindells, Julia. Victorian Writing and Working Women: The Other Side of Silence. Minneapolis: University of Minnesota Press, 1985. Print.

"Wilkie Collins (1824-1889)". Nineteenth-Century Literature Criticism 93. Ed. Juliet Byington. Detroit: Gale Group (2001): 1-94. Literary Criticism Online. Web. 28 June 2013. 
Franke 43

\section{Appendix}

Appendix A: Facsimile of first serialization of The Woman in White in All the Year Round

Chasles Diellens.

ALL THE YEAR ROUND.

Rownitur an, teas 195

that it was the peacefullest man's face ever be. held there. Many added that he looked subline and prophetie.

One of the most remarkable sufferers by the same axe $-\mathrm{a}$ woman-had asked at the foot of the same scaffold, not long before, to be allowed a to write down the thonghts that were inspiring her. If lie lad given any utteranee to his, and they vere prophetic, they would hare been these:

"I see Barsad, and Cly, Defarge, The Vengennce, the Juryman, the Judge, long mank of tlue new oppressots who have risen on the dc. struction of the old, perishing by this retributire instrument, before it shall cease out of its present use. I see a benutiful city and a brilliant people rising from this abyss, and, in their struggies to be truly free, in their trimmphs nod defents, through long long yenrs to come, I see the evil of this time and of the previous time of which this is the natural birth, gri dnally making expiation for itself and wearing ont.

"I see the lives for which I lay down uny life, peaceful, useful, prosperons and happy, in that England which I shall see no more, T see Hir with a child upon her bosen, who bears ny name. I see ber father, aced and bent, but otherwise restored, and faithful to sll mea in his healing ofice, and at pence. I see the good old minn, so long their friend, in ten years time enriching thein with all be has, and passin tranquilly to his reward.

"I see that I hold a stmetnary in their bearts and in the henrts of their descendants, goacri tions heace. I see her, an old womn, toeping for me on the anniversary of this diny. I see her and her hesband, their eontrse done, Jing side by side in their last earthly bed, and 1 linow that each was not more honoured and held saered in the other's soul, than I was in the souls of both.

"I see that child who hay upon ber boson and who bore my name, a man, vinning his way up in that path of life which ence was mine. 1 see him wisning it so well, that my name is made illustrions there by the light of his. I see the blots I threw upon it, failed away. I see him, foremost of just judges and homoured men, bringing a boy of my nume, with a forchest that I kpow and golden hair, to this placethen fafr to look upon, with not a trace of this day's disfigmerment-and I hear him tell thechild my story, with a tender and a faltering voice,

"It is a far, far betfer thing that I do, than I hare crer done; it is a far, far better rest that I go to, than I have ever known."

THE EXD.

Wx purpose always reserving the first place in these pages for a continuons origial work of fiction, occupying about the same amount of time in its serial publieation, as that which is just completed. The sccond story of our series

we now beg to imtrodece to the attention of our readers. It will poss, next week, into the station hitherto occupied by A Tale of Two Cities. And it is our hope and aim, while we work hard at every other department of oar journal, to produce, in this one, some sustnined works of imagination that may become a part of Finglish Literature.

\section{THE WOMAX:IN WHITE.}

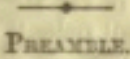

Trns is the story of what a Woman's patience An endure, and of what a Man's resolutiou can achieve.

If the machinery of the Law could be depended on to fathom every case of suspicion, and to conduet every process of inquiry, with moderate assistance onis from the inbricating influences of oil of gold, the events which fill these pages mieht bare elaimed tbcir share of the public attention in a Conrt of Justice.

Bat the Lav is still, in eertain ineritable cases, the pre-cngaged scrrant of the long purse ; and the stary is left to be told, for the first time, in this place. As the Jedre might once lare henrd it, so the Icader shall bear it now. No cirenmetance of importases, froa the beginning to the end of the disclosare, shall be related on hesirssy evidence. When the writer of these it. troductory lines (Walter Hartright, by mame) happens to be more closely conneeted than others with the incideats to be recorded, he will deseribe them in his own person. When his experience fails, he will retire from the poeition of narrator; and his task will be continued, froea the point at which he has left it off, hy other persous who can speak to the cirenm. stinees minder aotice from their own knowiedge, just as elearly and positively as he has spoken before then.

Thus, the story here prosented vill be told by more than one pen, as the story of an offence against the lavs is told in Court by more than one vitness-with the sarne objeet, in both eases, to present the truth alwass in its most direet and most intelligitle sspect; and to trnee the course of one complete series of events, by making the persons vho have been most closely connected with then, at ench saccessire stage, relate their omn experiener, word for word.

Let Walter Hartright, teacher of drawing, aged trenty-eight years, be heard first.

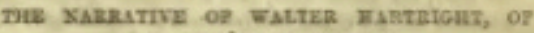
CLExes?'s 1SY, LOXDOS.

Ir was the last day of July. 'The loag hot summer was drawing to a elose; and we, the weary pilgrims of the Loedon parement, were beginning to think of the cloud-shadows on 
Franke 44

Appendix B: Family Tree in The Woman in White

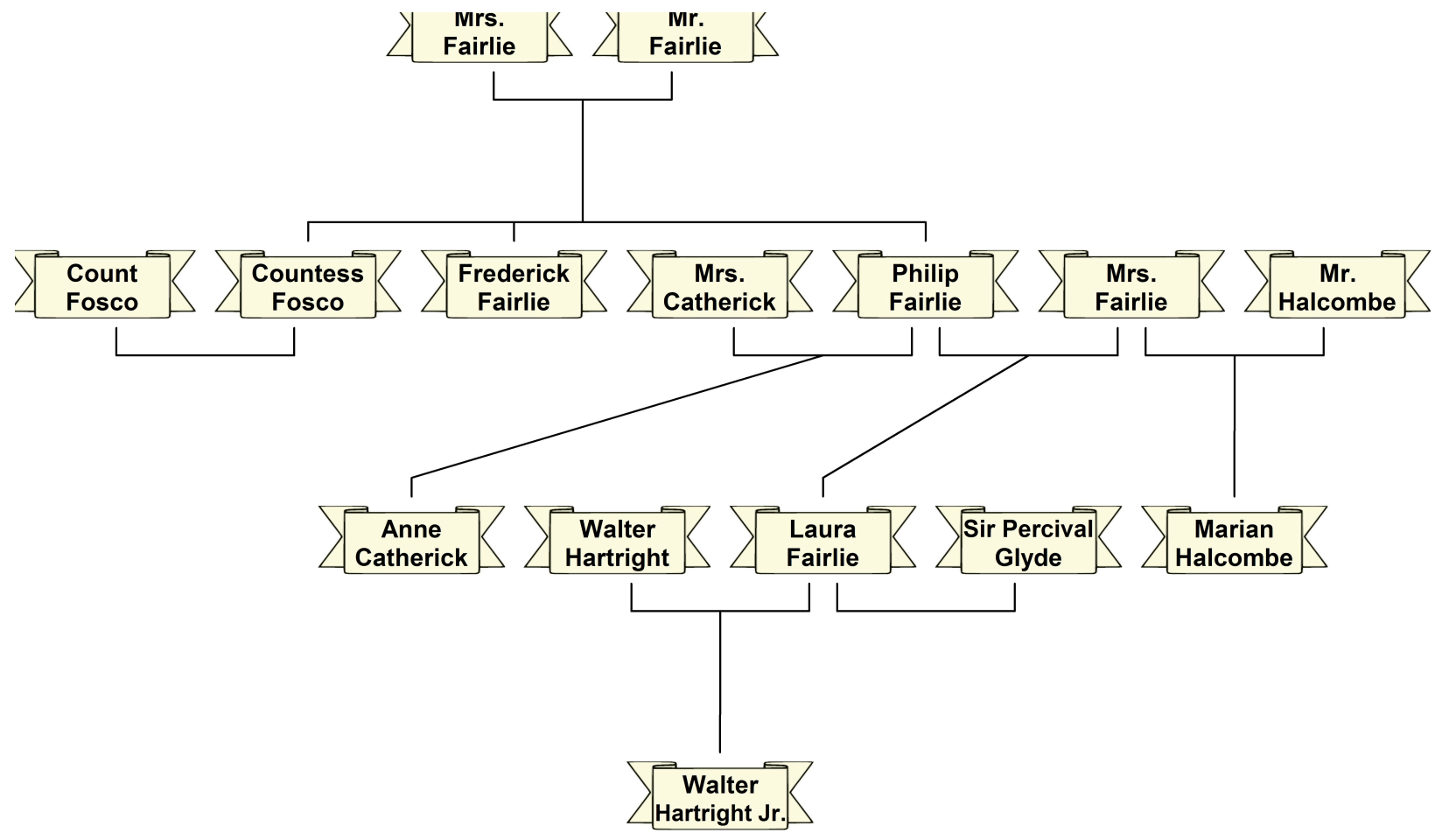


Appendix C: Order of Narration

\begin{tabular}{|l|l|}
\hline \multicolumn{1}{|c|}{ Serialization(s) } & \multicolumn{1}{|c|}{ Narrator } \\
\hline $1-7$ & Walter Hartright \\
\hline $8-9$ & Vincent Gilmore \\
\hline $10-19$ & Marian Halcombe \\
\hline 19 & Count Fosco \\
\hline $19-23$ & Fredrick Farlie \\
\hline $23-25$ & Eliza Michelson \\
\hline 25 & Hester Pinhorn \\
\hline 25 & Dr. Alfred Goodricke \\
\hline 25 & “Tombstone” \\
\hline $25-35$ & Walter Hartright \\
\hline $35-36$ & Mrs. Catherick \\
\hline $36-40$ & Walter Hartright \\
\hline 40 & Count Fosco \\
\hline 40 & Walter Hartright \\
\hline
\end{tabular}


Appendix D: The Woman in White and Wilkie Collins's Private Letters

\begin{tabular}{|c|c|}
\hline Date & Event \\
\hline April 1859 & All the Year Round begins publishing \\
\hline August 7, 1859 & Letter to Charles Ward \\
\hline August 18, 1859 & Letter to Charles Ward \\
\hline August 30, 1859 & Letter to Charles Ward \\
\hline September 2, 1859 & Letter to Mrs Harriet Collins \\
\hline September 7, 1859 & Letter to Charles Ward \\
\hline November 26, 1859 & 1st Number of The Woman in White (WIW) \\
\hline December 3, 1859 & 2nd Number of $W I W$ \\
\hline December 10,1859 & 3rd Number of $W I W$ \\
\hline December 17,1859 & 4th Number of $W I W$ \\
\hline December 24, 1859 & 5th Number of $W I W$ \\
\hline December 31,1859 & 6th Number of $W I W$ \\
\hline January 7,1860 & 7th Number of $W I W$ \\
\hline “ & Letter to E.M. Ward \\
\hline January 11,1860 & Letter to Richard Griffin \& Co. \\
\hline “ & Letter to Charles Ward \\
\hline January 13,1860 & Letter to Smith Elder \& Co. \\
\hline January 14,1860 & 8th Number of $W I W$ \\
\hline January 21,1860 & 9th Number of $W I W$ \\
\hline January 28,1860 & 10th Number of $W I W$ \\
\hline February 4, 1860 & $\begin{array}{l}\text { 11th Number of } W I W \\
\text { End of Vol. } 1 \text { for } 18603 \text { Volume Edition } \\
\text { End of } 1 \text { st Epoch for the } 1861 \text { New Edition }\end{array}$ \\
\hline
\end{tabular}




\begin{tabular}{|c|c|}
\hline Date & Event \\
\hline February 11,1860 & 12th Number of $W I W$ \\
\hline February 15,1860 & Letter to William Henry Wills \\
\hline February 18,1860 & 13th Number of $W I W$ \\
\hline February 25,1860 & 14th Number of $W I W$ \\
\hline March 3, 1860 & 15th Number of $W I W$ \\
\hline March 10, 1860 & 16th Number of $W I W$ \\
\hline March 17, 1860 & 17th Number of $W I W$ \\
\hline March 24, 1860 & 18th Number of $W I W$ \\
\hline March 31, 1860 & 19th Number of $W I W$ \\
\hline April 7, 1860 & 20th Number of $W I W$ \\
\hline April 14, 1860 & 21 st Number of $W I W$ \\
\hline April 21, 1860 & 22nd Number of $W I W$ \\
\hline April 28, 1860 & 23rd Number of $W I W$ \\
\hline May 5,1860 & 24th Number of $W I W$ \\
\hline May 12,1860 & 25th Number of $W I W$ \\
\hline May 19,1860 & $\begin{array}{l}\text { 26th Number of WIW } \\
\text { End of Vol. } 2 \text { for } 18603 \text { Volume Edition } \\
\text { End of } 2 \text { nd Epoch for the } 1861 \text { New Edition }\end{array}$ \\
\hline May 26,1860 & 27th Number of $W I W$ \\
\hline June 1860 & Letter to Charles Ward \\
\hline June 2,1860 & 28th Number of $W I W$ \\
\hline June 9,1860 & 29th Number of $W I W$ \\
\hline June 16,1860 & 30th Number of $W I W$ \\
\hline June 23,1860 & 31st Number of $W I W$ \\
\hline “ & Letter to Mrs. Anne Procter \\
\hline
\end{tabular}




\begin{tabular}{|c|c|}
\hline Date & Event \\
\hline June 30,1860 & 32nd Number of $W I W$ \\
\hline July 7,1860 & 33rd Number of $W I W$ \\
\hline July $14 \mathrm{~m} 1860$ & 34th Number of $W I W$ \\
\hline July 21, 1860 & 35th Number of $W I W$ \\
\hline July 23, 1860 & Letter to Mrs. Anne Procter \\
\hline July 26, 1860 & Letter to Mrs Harriet Collins \\
\hline July 28,1860 & 36th Number of $W I W$ \\
\hline August 1,1860 & Letter to William Holman Hunt \\
\hline August 4, 1860 & 37th Number of $W I W$ \\
\hline August 7, 1860 & Letter to Charles Dickens \\
\hline August 8, 1860 & Letter to Mrs. Anne Procter \\
\hline August 11, 1860 & 38th Number of $W I W$ \\
\hline August 14,1860 & Letter to Charles Ward \\
\hline August 18, 1860 & 39th Number of $W I W$ \\
\hline August 25, 1860 & $\begin{array}{l}\text { 40th Number of } W I W \\
\text { End of Vol. } 3 \text { for } 18603 \text { Volume Edition } \\
\text { End of 3rd Epoch for the } 1861 \text { New Edition }\end{array}$ \\
\hline August 28, 1860 & Letter to Nugent Robinson \\
\hline August 1860 & Three Volume Edition published \\
\hline September 12, 1860 & Letter to Mrs Harriet Collins \\
\hline October 3,1860 & Letter to Mrs Harriet Collins \\
\hline October 10,1860 & Letter to Charles Ward \\
\hline October 31,1860 & Letter to Edward Marston \\
\hline 1861 & New Edition published \\
\hline
\end{tabular}


Appendix E: Serialized Numbers Compared to 1860 and 1861 "New Edition” Chapters 4

\begin{tabular}{|c|c|}
\hline Serialized Edition & $1860 \& 1861$ New Edition \\
\hline 1st Number of The Woman in White (WIW) & Chapters 1-4 \\
\hline 2nd Number of $W I W$ & Chapters 5-7 \\
\hline 3rd Number of $W I W$ & Chapter 8 \\
\hline 4th Number of $W I W$ & Chapters 9-10 \\
\hline 5th Number of $W I W$ & Chapters 11-12 \\
\hline 6th Number of $W I W$ & Chapter 13 \\
\hline $\begin{array}{l}\text { 7th Number of } W I W \\
\text { End of a Narrative }\end{array}$ & Chapters 14-15 \\
\hline 8th Number of $W I W$ & Chapters 1-2 \\
\hline $\begin{array}{l}\text { 9th Number of } W I W \\
\text { End of a Narrative }\end{array}$ & Chapters 3-4 \\
\hline 10th Number of $W I W$ & Chapter 1 \\
\hline $\begin{array}{l}\text { 11th Number of } W I W \\
\text { End of Vol. } 1 \text { for } 18603 \text { Volume Edition } \\
\text { End of } 1 \text { st Epoch for the } 1861 \text { New Edition }\end{array}$ & Chapter 2 \\
\hline 12th Number of $W I W$ & Chapter 1 \\
\hline 13th Number of $W I W$ & Chapter 2 \\
\hline 14th Number of $W I W$ & Chapter 3 \\
\hline 15 th Number of $W I W$ & Chapter 4 \\
\hline 16th Number of $W I W$ & Chapter 5 \\
\hline 17 th Number of $W I W$ & Part of Chapter 6 \\
\hline 18th Number of $W I W$ & Rest of Chapter 6 \\
\hline 19th Number of $W I W$ & Chapter 7 \\
\hline 20th Number of $W I W$ & Chapter 8- Part of Chapter 9 \\
\hline
\end{tabular}

\footnotetext{
${ }^{4}$ Collins formatted his texts so that the chapter numbers started all over again at the start of a new narrative.
} 


\begin{tabular}{|c|c|}
\hline Serialized Edition & $1860 \& 1861$ New Edition \\
\hline 21 st Number of $W I W$ & Rest of Chapter 9 \\
\hline 22nd Number of $W I W$ & Part of Chapter 10 \\
\hline $\begin{array}{l}\text { 23rd Number of } W I W \\
\text { Narrator Changes Midway Through }\end{array}$ & Rest of Chapter 10 and Part of Chapter 1 \\
\hline 24th Number of $W I W$ & Rest of Chapter 1 \\
\hline 25th Number of $W I W$ & Part of Chapter 2 \\
\hline $\begin{array}{l}\text { 26th Number of } W I W \\
\text { End of Vol. } 2 \text { for } 18603 \text { Volume Edition } \\
\text { End of 2nd Epoch for the } 1861 \text { New Edition }\end{array}$ & Rest of Chapter 2 \\
\hline 27th Number of $W I W$ & Chapter 1- Part of Chapter 2 \\
\hline 28th Number of $W I W$ & Rest of Chapter 2- Chapter 3 \\
\hline 29th Number of $W I W$ & Chapter 4 \\
\hline 30th Number of $W I W$ & Chapters 5-6 \\
\hline 31 st Number of $W I W$ & Chapter 7 \\
\hline 32nd Number of $W I W$ & Chapter 8 \\
\hline 33rd Number of $W I W$ & Chapter 9 \\
\hline 34th Number of $W I W$ & Chapter 10 \\
\hline 35th Number of $W I W$ & Part of Chapter 11 \\
\hline $\begin{array}{l}\text { 36th Number of WIW } \\
\text { Narrator Changes Midway Through }\end{array}$ & Rest of Chapter 11 and Chapter 1 \\
\hline 37th Number of $W I W$ & Chapter 2 \\
\hline 38th Number of $W I W$ & Chapter 3 \\
\hline 39th Number of $W I W$ & Chapter 4 - Part of Chapter 7 \\
\hline $\begin{array}{l}\text { 40th Number of WIW } \\
\text { Narrator Changes Midway Through } \\
\text { End of Vol. } 3 \text { for } 18603 \text { Volume Edition } \\
\text { End of 3rd Epoch for the } 1861 \text { New Edition }\end{array}$ & Rest of Chapter 7 and Chapters 1-3 \\
\hline
\end{tabular}


Franke 51 